Review article

\title{
Barriers to the adoption of evidence-based practice among nurses
}

\author{
Maria Pitsillidou ${ }^{*}$, Zoe Roupa ${ }^{2}$, Antonis Farmakas ${ }^{2}$, Maria Noula ${ }^{2}$ \\ ${ }^{1}$ Evangelistria Medical Center, Nicosia, Cyprus \\ ${ }^{2}$ University of Nicosia, Department of Life and Health Sciences, Nicosia, Cyprus
}

\begin{abstract}
Aim: The purpose of this review was to investigate the barriers preventing nurses from evaluating and applying evidence from research findings in their nursing practice.

Background: Evidence-based practice, a recent addition to the nursing literature, has been reported to promote beneficial outcomes. The investigation of factors influencing its adoption and, in particular, the integration of empirical evidence with nursing practice is warranted.

Methods: A systematic review was performed using databases, such as PubMed, CINAHL, Health Source: Nursing/Academic Edition, and MEDLINE, to access articles published between 2008 and 2017. A total of 14 studies met the selection criteria and were included in the study. This review was undertaken in accordance with the PRISMA guidelines.

Results: The main barrier hindering the integration of research evidence into practice, and consequently, the application of evidence-based practice to nursing was nurses' lack of time to conduct searches and read research articles. At the same time, many other factors, which are common among studies, appeared to influence differences in the nurses' incorporation of research evidence into their practice.

Conclusions: There is a significant gap between research and nursing practice. Identifying the factors contributing to this gap might provide a foundation for developing strategies to reconcile it.
\end{abstract}

Keywords: Barriers; Evidence-based practice; Healthcare; Hospital; Nursing; Research utilization

\section{Introduction}

Evidence-based practice (EBP) has been a priority in nursing practice over the last few years at the international level. A considerable number of studies conducted worldwide have highlighted EBP's importance (Saunders et al., 2019; Shayan et al., 2019; Thorsteinsson and Sveinsdottir, 2014). It has been defined as 'a continuous interactive process involving the conscientious and wise examination of available research evidence for better care' (Canadian Nurses Association, 2010). The daily accumulation of new knowledge and technologies, consumers' changing needs, and finding, retrieving, and using existing knowledge based on research evidence in practice are basic concerns of nurses (Farokhzadian et al., 2015). Nursing services play a key role in the effectiveness of health systems (WHO, 2010), and nurses' clinical decisions are essential for patients' well-being and treatment outcomes (Thorsteinsson, 2013).

The application of evidenced-based practice benefits both patients and nurses. Healthcare systems, which in recent years have been under pressure to save resources and improve service performance, report positive outcomes (Leach et al.,
2016; Melnyk et al., 2010; Orta et al., 2016). Attempts to improve the quality of healthcare services and to use available resources rationally have led to repeated attempts to adopt EBP (Lau et al., 2016; Orta et al., 2016).

Although the application of EBP in nursing has been universally acknowledged as a way to improve healthcare services, its complexity due to multiple factors has prevented its application (Saunders et al., 2016). Barriers to research utilization in nursing have been extensively reported in the literature (Duncombe, 2018; Kiessling et al., 2011; Veeramah, 2016). The results of studies on barriers to the use of EBP differ and there is great ambiguity and confusion in defining the greatest barriers. Studies show that nurses rarely incorporate research findings into their practice, as they tend to use practices derived from pre-existing knowledge, experiences, and social interactions (Friesen-Storms et al., 2015; Gifford et al., 2018; Stokke et al., 2014).

\section{Aim}

The purpose of this research was to investigate the factors that impede the use of research evidence in the application of EBP to the clinical practice of nurses.

\footnotetext{
* Author for correspondence: Maria Pitsillidou, Evangelistria Medical Center, Michael Giorgalla 1, Egkomi 1095, Nicosia, Cyprus; e-mail: maria_pitsillidou@outlook.com http://doi.org/10.32725/kont.2020.017 


\section{Materials and methods}

A systematic review of the international literature was conducted. In the creation of this paper, the content analysis method was used. The relevant sources were searched using the scientific databases PubMed, CINAHL, Health Source: Nursing/Academic Edition, and MEDLINE. The survey was conducted in August 2017. Gathering of data and results analysis were carried out from January 2008 to June 2017. The search terms used were 'evidence-based practice', 'research utilization', 'nursing', and 'hospital' in the titles of articles, and the used Boolean operators were "AND" and "OR". The results are presented in a PRISMA - Suppl. file 1: PRISMA 2009 Flow Diagram: selection strategy of studies for systematic review (Moher et al., 2015).

During the first phase of the search, 1,268 papers were found. In the next phase of the analysis, all duplicates and studies that did not deal with the topic in the required context were removed. Also removed were studies older than 10 years and studies for which I was unable to obtain their full text. The resulting number of studies used for this review was 14 papers. These 14 papers were conducted in the US, Singapore, England, Iran, Kenya, Norway, Turkey, Oman and China, with samples ranging from 182 to 1,486 participants.

The key features of all the included studies (i.e. authors, year of publication, country where the study was conducted, number of participants, research objective, data collection tools, and key research results) are summarized in Table 1.

An attempt was made to include only randomized studies, but this was impossible because of the limited number of this type of study. A quantitative synthesis of the results was not performed; only a systematic review of the studies was conducted. Specific tools were not used to assess the quality of the studies because the purpose of this review was descriptive.

\section{Inclusion and exclusion criteria}

This systematic review focused on identifying studies published in English or Greek. Studies (qualitative, quantitative, or mixed-methods) consisting of nurses working in hospitals or medical centres, aged 21-65 years, were selected for the review. Surveys of primary care nurses, nursing students, or other healthcare professionals were excluded. No secondary analyses were included that did not fully investigate the subject under study.

\section{Results}

Fourteen international studies from the US (2), Singapore (2), England (1), Iran (1), Kenya (1), Norway (1), Turkey (3), and Oman (2) were reviewed. Although a considerable number of international studies have been conducted on research utilization in the healthcare field, few have examined barriers affecting the application of research findings to nursing practice; yet, nurses are one of the largest groups of health professionals and have key roles in the care of patients. The number of studies on this topic using randomization was even fewer. A large number of studies were excluded from this review because most of them included other health professionals (e.g. midwives and doctors) or primary care nurses and nursing students. The analysis of the 14 studies eligible for this systematic review revealed interesting results. Some of the studies had common features, such as use of the same instrument, i.e. the Barriers Scale $(n=8)$, although this feature was not a criterion for the selection of studies.

This review found that the main barriers influencing the application of EBP were mostly organizational shortcomings and malfunctions. The results of the 14 studies showed the majority of nurses considered lack of time as one of the major barriers to research utilization in their clinical practice, with an agreement of $85.7 \%(n=12)$ between the studies (Ammouri et al., 2014; Brown et al., 2009; 2010; Dalheim et al., 2012; Foo et al., 2011; Gerrish et al., 2008; Majid et al., 2011; Sari et al., 2012; Tan et al., 2012; Wang et al., 2013; Yava et al., 2009; Zhou et al., 2015). Lack of time was found to be the greatest obstacle in six of the studies (Brown et al., 2009; 2010; Dalheim et al., 2012; Foo et al., 2011; Gerrish et al., 2008; Majid et al., 2011) and one of the top five barriers in the remaining studies $(n=6)$ (Ammouri et al., 2014; Sari et al., 2012; Tan et al., 2012; Wang et al., 2013; Yava et al., 2009; Zhou et al., 2015). In the survey by Brown et al. (2009), respondents said they had limited time to search for studies during scheduled work hours and after work: 'very little time to find and read research' and 'too many family responsibilities to read research at home'.

Lack of time was considered by many investigations (Brown et al., 2009; 2010; Dalheim et al., 2012; Foo et al., 2011; Gerrish et al., 2008; Majid et al., 2011) as the main factor interfering with the adoption of EBP; in other studies, nurses had different perceptions (Ammouri et al., 2014; Sari et al., 2012; Tan et al., 2012; Wang et al., 2013; Yava et al., 2009; Zhou et al., 2015). Barriers were considered to reflect a lack of power to make changes in practice (Brown et al., 2009; 2010; Tan et al., 2012; Wang et al., 2013; Yava et al., 2009), lack of time to make changes in practice (Brown et al., 2010; Foo, et al. 2011; Tan et al., 2012; Zhou et al., 2015), and inadequate workplace facilities for the use of research findings (Mutisya et al., 2015; Sari et al., 2012; Yava et al., 2009). These factors were among the most frequently encountered barriers.

Almost all the studies showed similar findings with respect to EBP barriers, with differences in their rank order by importance of the barriers. Lack of skills for finding and managing research evidence, the inability to understand statistical terms used in research articles, lack of relevant references or references obtained from only one source, and poor knowledge of research were reported as barriers, although to different degrees (Ammouri et al., 2014; Brown et al., 2009; 2010; Dalheim et al., 2012; Farokhzadian et al., 2015; Foo et al., 2011; Gerrish et al., 2008; Majid et al., 2011; Tan et al., 2012; Sari et al., 2012; Wang et al., 2013; Zhou et al., 2015).

Several studies reported different outcomes, such as those by Mutisya et al. (2015) and Ammouri, et al., (2014) conducted in Kenya and Oman, respectively, which identified difficulty finding research reports or the unavailability of research studies as a major barrier to the implementation of EBP. This barrier was not identified in any of the other studies as the most important barrier influencing the adoption of EBP. Different results were also reported by Farokhzadian et al. (2015). In that study, the greatest barrier for the implementation of EBP was difficulty assessing the quality of research articles, a barrier that nurses from the other studies classified as important but not as the greatest barrier. Two other studies (Dalheim et al., 2012; Wang et al., 2013) conducted in countries that do not have English as their first language reported that the publication of research articles in English was a major barrier to research utilization in practice. 


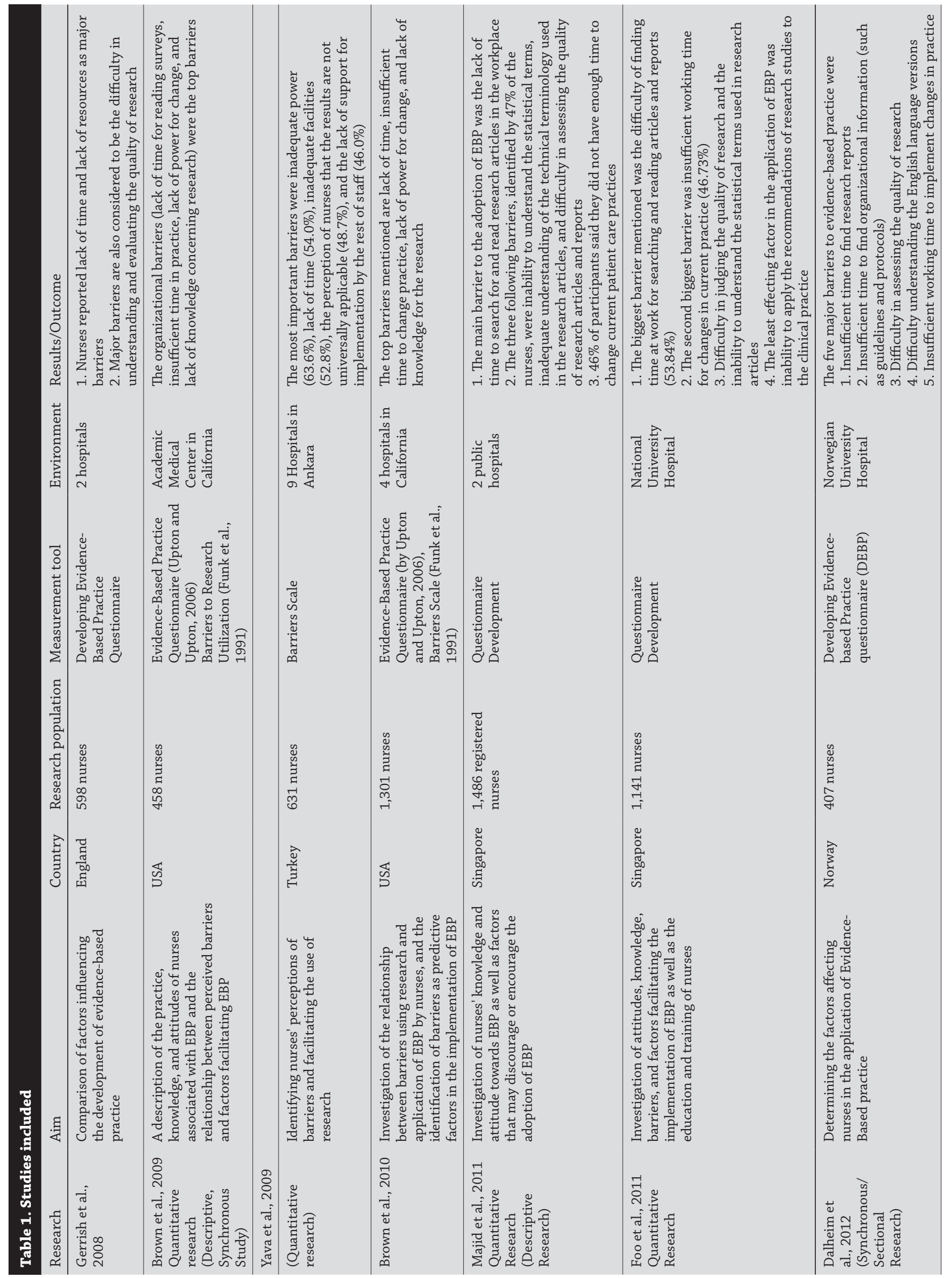




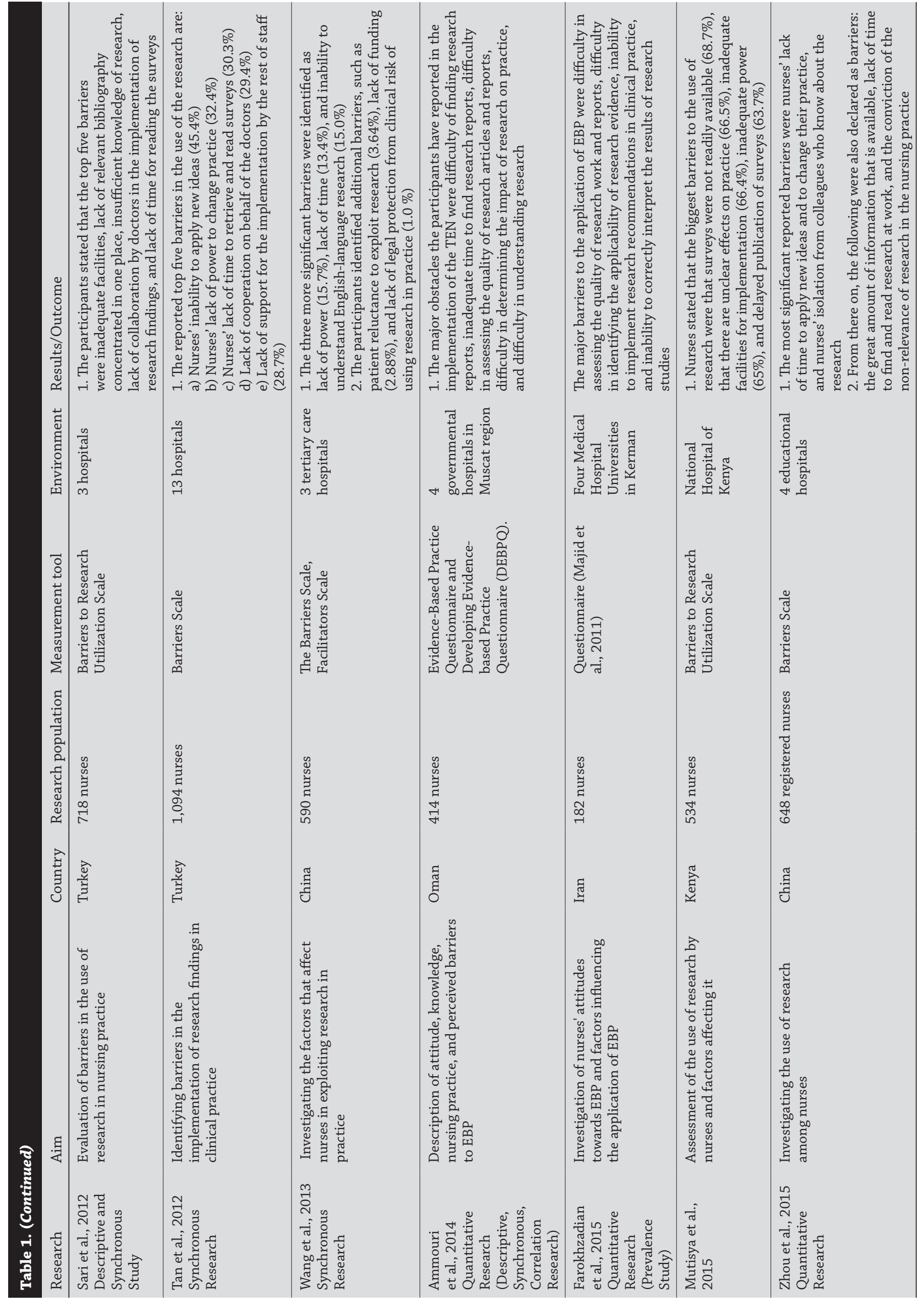




\section{Discussion}

This review's results showed that the implementation of EBP is not easy, and that a multitude of factors, such as organizational barriers affect the application of research findings. This review revealed lack of time as one of the greatest barriers to the application of research findings in clinical practice. Studies that were excluded from this review because their samples consisted of populations other than those required for this study (e.g. primary care nurses, nursing students, or other health professionals) also found the same results. Studies have reported that these professionals do not have enough time to search for and read research papers and reports (Atkinson et al., 2008; Breimaier et al., 2011; Chau et al., 2008; Koehn and Lehman, 2008; Mehrdad et al., 2008; O'Connor and Pettigrew, 2009). The review by Sadoughi et al. (2017) of studies of nurses also found that lack of sufficient time was the most frequently mentioned barrier in $86 \%$ of the studies. Although a barrier, lack of time might also reflect lack of interest, lack of need for new knowledge, or lack of knowledge. Nurses might wish to avoid additional responsibilities or tasks, such as the process of exploiting research findings (Ozdemir and Akdemir, 2009).

Lack of power to change nursing practice, which emerged as a barrier in this review, has been identified as a major barrier in other reviews (Al Ghabeesh, 2015; Heydari and Zeydi, 2014). Lack of power might be related to the prevailing hierarchical structure of modern hospitals, as directors and physicians have power roles, whereas nurses appear to be executive bodies, thus, undermining their role (Yava et al., 2009). Similarly, inadequate facilities for the application of EBP has also been reported as a barrier, not only by nurses but also by other health professionals in studies conducted in many countries (China, Nepal, Ireland, Bahrain, Turkey and Spain) (Buhaid et al., 2014; Chien et al., 2013; Mehrdad et al., 2008; Moreno-Casbas et al., 2011; Srijana et al., 2016; Uysal et al., 2010). A lack of essential equipment and facilities leads to limited use of research findings. Moreover, the economy of a country plays a major role in this barrier, as nurses from more developed countries, such as Norway and the US did not share the same opinions (Brown et al., 2009; 2010; Dalheim et al., 2012). Many nurses also reported an inability to assess the quality of research reports, which is probably due to their low levels of research knowledge (Linton and Prasun, 2013).

Agreement with regard to nurses' lack of time to implement new ideas and changes in practice was found in this review. In another review study (Athanasakis, 2013), 23 of the 37 investigations classified insufficient time to implement new ideas as one of the top five barriers. Finally, a significant obsta- cle was that published research was available only in English. Difficulty reading English journals can cause many misunderstandings in the application of EBP in nursing (Wang et al., 2013).

\section{Conclusions}

In summary, the findings of this review showed that the same top barriers were classified similarly by nurses in different countries despite their cultural differences. Furthermore, the findings suggest that lack of time to access and read research is the most important factor in the inability to use research findings in practice, and consequently, in the adoption of EBP by nurses. The reasons for the lack of time to engage in these activities are not clear and warrant further investigation. The reasons may concern issues, such as time management, role overload, or priorities.

According to the international literature and contrary to expectations, research utilization in nursing practice remains limited, despite the positive attitudes which nurses present. Recent literature has reported significant gaps between research and nursing practice. The adoption of EBP is a relatively new approach, which has beneficial effects on health and on the healthcare system (Leach et al., 2016; Orta et al., 2016; Saunders and Vehviläinen-Julkunen, 2015; Saunders et al., 2016), but it requires proper guidance and education. The knowledge of the barriers will help the health system and policy makers to address these and to provide a positive culture to the EBP. In any case, organizational strategies must be in place to encourage and support nurses at all stages of the nursing process to base their practice on research evidence.

\section{Acknowledgements}

This study is part of the researcher's thesis at the Nursing Department of Nicosia University, Cyprus. The author is grateful to the research team for its help in writing this systematic review.

\section{Funding}

This systematic review was not funded.

\section{Ethical approval}

This study does not require approval from the National Bioethics Committee of Cyprus.

\section{Conflict of interests}

The authors have no conflict of interests to report. 


\section{Bariéry implementace ošetřovatelství založeného na důkazech zdravotními sestrami do praxe}

\section{Souhrn}

Cíl: Cílem této přehledové studie bylo prozkoumat bariéry, které brání zdravotním sestrám ve vyhodnocení a aplikování poznatků získaných vědeckým výzkumem do jejich ošetřovatelské praxe.

Úvod: Ošetřovatelství založené na důkazech je v odborné literatuře relativně novým jevem a přináší zajímavé výsledky. Je žádoucí provést výzkum faktorů, které ovlivňují přijetí těchto postupů do praxe, a zejména zjistit, jak jsou empirické poznatky do ošetřovatelské praxe implementovány.

Metodika: Systematická přehledová studie, při které byly s pomocí databází jako PubMed, CINAHL, Health Source: Nursing/ Academic Edition a MEDLINE prohledány vědecké články publikované v letech 2008 až 2017. Celkem vyhovělo daným kritériím 14 publikací, které byly následně zařazeny do této studie, jež byla provedena v souladu s pokyny PRISMA.

Výsledky: Hlavní překážkou v implementaci ošetřovatelství založeného na důkazech do praxe byl nedostatek času, který zdravotní sestry mají na vyhledávání a čtení odborných článků. Kromě nedostatku času se v publikacích opakovaly i mnohé další faktory, jež ovlivňovaly rozdíly mezi zdravotními sestrami v přejímání vědeckých poznatků do jejich ošetřovatelské praxe.

Závěr: Existuje významný rozdíl mezi vědeckými poznatky a ošetřovatelskou praxí. Identifikace faktorů by mohla být základem ke stanovení strategií při využívání principů ošetřovatelství založeného na důkazech.

Kličová slova: aplikace výzkumu; bariéry; nemocnice; ošetřovatelství založené na důkazech; zdravotnictví

\section{References}

1. Al Ghabeesh SH (2015). Barriers and suggested facilitators to the implementation of best practice: an integrative review. Open Journal of Nursing 5(1): 77-87. DOI: 10.4236/ ojn.2015.51009.

2. Ammouri AA, Raddaha AA, Dsouza P, Geethakrishnan R, Noronha JA, Obeidat AA, Shakman L (2014). Evidence-based practice: knowledge, attitudes, practice and perceived barriers among nurses in Oman. Sultan Qaboos Univ Med J 14(4): e537-545. PMID: 25364558.

3. Athanasakis E (2013). Nurses' research behavior and barriers to research utilization into clinical nursing practice: a closer look. International Journal of Caring Sciences 6(1): 16-28.

4. Atkinson M, Turkel M, Cashy J (2008). Overcoming barriers to research in a Magnet community hospital. J Nurs Care Qual 23(4): 362-368. DOI: 10.1097/01.NCQ.0000336675.48466.37.

5. Breimaier HE, Halfens RJ, Lohrmann C (2011). Nurses' wishes, knowledge, attitudes and perceived barriers on implementing research findings into practice among graduate nurses in Austria. J Clinic Nurs 20(11-12): 1744-1756. DOI: 10.1111/j.1365-2702.2010.03491.x.

6. Brown CE, Ecoff L, Kim SC, Wickline MA, Rose B, Klimpel K, Glaser D (2010). Multi-institutional study of barriers to research utilisation and evidence-based practice among hospital nurses. J Clinic Nurs 19(13-14): 1944-1951. DOI: 10.1111/j.1365-2702.2009.03184.x.

7. Brown CE, Wickline MA, Ecoff L, Glaser D (2009). Nursing practice, knowledge, attitudes and perceived barriers to evidence-based practice at an academic medical center. J Advanced Nurs 65(2): 371-381. DOI: 10.1111/j.13652648.2008.04878.x.

8. Buhaid N, Lau R, O'Connor M (2014). A survey of nurses' perceived barriers to research utilization in Bahrain in comparison to other countries. Middle East J Nurs 8(2): 3-9. DOI: 10.5742/MEN.2014.92475.

9. Canadian Nurses Association (2010). Position Statement: Evidence Informed Decision-making and Nursing Practice. Ottawa: Author.

10. Chau JP, Lopez V, Thompson DR (2008). A survey of Hong Kong nurses' perceptions of barriers to and facilitators of research utilization. Res Nurs Health 31(6): 640-649. DOI: 10.1002/ nur.20289.
11. Chien WT, Bai Q, Wong WK, Wang H, Lu X (2013). Nurses' perceived barriers to and facilitators of research utilization in mainland china: a cross-sectional survey. Open Nurs J 7: 96-106. DOI: 10.2174/1874434601307010096.

12. Dalheim A, Harthug S, Nilsen RM, Nortvedt MW (2012). Factors influencing the development of evidence-based practice among nurses: a self-report survey. BMC Health Serv Res 24(12): 367. DOI: 10.1186/1472-6963-12-367.

13. Duncombe DC (2018). A multi-institutional study of the perceived barriers and facilitators to implementing evidencebased practice. J Clin Nurs 27(5-6): 1216-1226. DOI: 10.1111/ jocn.14168.

14. Farokhzadian J, Khajouei R, Ahmadian L (2015). Evaluating factors associated with implementing evidence-based practice in nursing. J Eval Clin Pract 21: 1107-1113. DOI: 10.1111/ jep. 12480 .

15. Foo S, Majid S, Mokhtar IA, Zhang X, Luyt B, Chang YK, Theng YL (2011). Nurses' perception of evidence-based practice at the National University Hospital of Singapore. J Contin Educ Nurs 42(11): 522-528. DOI: 10.3928/0022012420110516-04.

16. Friesen-Storms JH, Moser A, Van der Loo S, Beurskens AJ, Bours GJ (2015). Systematic implementation of evidence-based practice in a clinical nursing setting: a participatory action research project. J Clin Nurs 24(1-2): 57-68. DOI: 10.1111/ jocn.12697.

17. Funk SG, Champagne MT, Wiese RA, Tornquist EM (1991). Barriers: the barriers to research utilization scale. Appl Nurs Res 4(1): 39-45. DOI: 10.1016/s0897-1897(05)80052-7.

18. Gerrish K, Ashworth P, Lacey A, Bailey J (2008). Developing evidence-based practice: experiences of senior and junior clinical nurses. J Adv Nurs 62(1): 62-73. DOI: 10.1111/j.13652648.2007.04579.x.

19. Gifford W, Zhang Q, Chen S, Davies B, Xie R, Wen S, Harvey G (2018). When east meets west: a qualitative study of barriers and facilitators to evidence-based practice in Hunan China. BMC Nursing 17: 26. DOI: 10.1186/s12912-018-0295-x.

20. Heydari A, Zeydi AE (2014). Barriers to and facilitators of research utilization among Iranian nurses: a literature review. J Caring Sci 3(4): 265-275. DOI: 10.5681/jcs.2014.029

21. Kiessling A, Lewitt M, Henriksson P (2011). Case-based training of evidence-based clinical practice in primary care and decreased mortality in patients with coronary heart disease. Ann Fam Med 9(3): 211-218. DOI: 10.1370/afm.1248. 
22. Koehn ML, Lehman K (2008). Nurses perceptions of evidence based nursing practice. J Adv Nurs 62: 209-215. DOI: 10.1111/j.1365-2648.2007.04589.x.

23. Lau R, Stevenson F, Ong BN, Dziedzic KT, Treweek S, Eldridge S, et al. (2016). Achieving change in primary care - causes of the evidence to practice gap: systematic reviews of reviews Implement Sci 11: 40. DOI: 10.1186/s13012-016-0396-4.

24. Leach MJ, Hofmeyer A, Bobridge A (2016). The impact of research education on student nurse attitude, skill and uptake of evidence-based practice: a descriptive longitudinal survey. J Clin Nurs 25(1-2): 194-203. DOI: 10.1111/jocn.13103.

25. Linton MJ, Prasun MA (2013). Evidence-based practice: collaboration between education and nursing management. J Nurs Manag 21(1): 5-16. DOI: 10.1111/j.13652834.2012.01440.x.

26. Majid S, Foo S, Luyt B, Zhang X, Theng Y, Chang Y, Mokhtar AI (2011). Adopting evidence-based practice in clinical decision making: nurses' perceptions, knowledge, and barriers. J Med Libr Assoc 99(3): 229-236. DOI: 10.3163/1536-5050.99.3.010.

27. Mehrdad N, Salsali M, Kazemnejad A (2008). The spectrum of barriers to and facilitators of research utilization in Iranian nursing. J Clin Nurs 17(16): 2194-2202. DOI: 10.1111/j.13652702.2007.02040.x

28. Melnyk BM, Fineout-Overholt E, Giggleman M, Cruz R (2010). Correlates among cognitive beliefs, EBP implementation, organizational culture, cohesion and job satisfaction in evidence-based practice mentors from a community hospital system. Nurs Outlook 58(6): 301-308. DOI: 10.1016/j. outlook.2010.06.002.

29. Moher D, Shamseer L, Clarke M, Ghersi DL, Liberati A, Petticrew M, et al. (2015). Preferred reporting items for systematic review and meta-analysis protocols (PRISMA-P) 2015 statement. Syst Rev 4(1). DOI: 10.1186/2046-4053-4-1.

30. Moreno-Casbas T, Fuentelsaz-Gallego C, Gil de Miguel A, Gonzalez-Maria E, Clarke SP (2011). Spanish nurses' attitudes towards research and perceived barriers and facilitators of research utilisation: a comparative survey of nurses with and without experience as principal investigators. J Clin Nurs 20(13-14): 1936-1947. DOI: 10.1111/j.13652702.2010.03656.x.

31. Mutisya AK, Karani AK, Kigondu C (2015). Research utilization among nurses at a teaching hospital in Kenya. J Caring Sci 4(2): 95-104. DOI: 10.15171/jcs.2015.010.

32. O'Connor S, Pettigrew CM (2009). The barriers perceived to prevent the successful implementation of evidence-based practice by speech and language therapists. Int J Lang Commun Disord 44(6): 1018-1035. DOI: 10.1080/13682820802585967.

33. Orta R, Messmer PR, Valdes GR, Turkel M, Fields SD, Wei CC (2016). Knowledge and Competency of Nursing Faculty Regarding Evidence-Based Practice. J Contin Educ Nurs 47(9): 409-419. DOI: 10.3928/00220124-20160817-08.

34. Ozdemir L, Akdemir N (2009). Turkish nurses' utilization of research evidence in clinical practice and influencing factors. Int Nurs Rev 56: 319-325. DOI: 10.1111/j.14667657.2009.00707.x.

35. Sadoughi F, Azadi T, Azadi T (2017). Barriers to using electronic evidence based literature in nursing practice: a systematised review. Health Info Libr J 34: 187-199. DOI: 10.1111/ hir.12186.

36. Sari D, Turgay AS, Genc RE, Bozkurt OD (2012). Research activities and perceptions of barriers to research utilization among Turkish Nurses. J Contin Educ Nurs 43(6): 251-258. DOI: 10.3928/00220124-20111115-05.
37. Saunders H, Vehviläinen-Julkunen K (2015). The state of readiness for evidence-based practice among nurses: an integrative review. Int J Nurs Stud 56: 128-140. DOI: 10.1016/j.ijnurstu.2015.10.018.

38. Saunders H, Gallagher-Ford L, Kvist T, Vehviläinen-Julkunen K (2019). Practicing Healthcare Professionals' Evidence-Based Practice Competencies: An Overview of Systematic Reviews. Worldviews Evid Based Nurs 16(3): 176-185. DOI: 10.1111/ wvn.12363.

39. Saunders H, Stevens KR, Vehviläinen-Julkunen K. (2016). Nurses' readiness for evidence-based practice at Finnish university hospitals: a national survey. J Adv Nurs 72(8): 1863-1874. DOI: 10.1111/jan.12963.

40. Shayan SJ, Kiwanuka F, Nakaye Z (2019). Barriers Associated With Evidence-Based Practice Among Nurses in Low- and Middle-Income Countries: A Systematic Review. Worldviews Evid Based Nurs 16(1): 12-20. DOI: 10.1111/wvn.12337.

41. Srijana KC, Subramaniam PR, Paudel S (2016). Barriers and facilitators of utilizing research among nurses in Nepal. J Contin Educ Nurs 47(4): 171-179. DOI: 10.3928/0022012420160322-07.

42. Stokke K, Olsen NR, Espehaug B, Nortvedt MW (2014). Evidence based practice beliefs and implementation among nurses: a cross-sectional study. BMC Nurs 13(1): 8. DOI: 10.1186/1472-6955-13-8.

43. Tan M, Sahin ZA, Özdemir FK (2012). Barriers of research utilization from the perspective of nurses in Eastern Turkey. Nurs Outlook 60(1): 44-50. DOI: 10.1016/j. outlook.2011.07.002.

44. Thorsteinsson HS (2013). Icelandic nurses' beliefs, skills, and resources associated with evidence-based practice and related factors: a national survey. Worldviews Evid Based Nurs 10(2): 116-126. DOI: 10.1111/j.1741-6787.2012.00260.x.

45. Thorsteinsson HS, Sveinsdóttir H (2014). Readiness for and predictors of evidence-based practice of acute-care nurses: a cross-sectional postal survey. Scand J Caring Sci 28(3): 572 -581 . DOI: $10.1111 /$ scs.12083.

46. Upton D, Upton P (2006). Development of an evidence-based practice questionnaire for nurses. J Adv Nurs 54(4): 454-458. DOI: 10.1111/j.1365-2648.2006.03739.x.

47. Uysal A, Temel AB, Ardahan M, Ozkahraman S (2010). Barriers to research utilisation among nurses in Turkey. J Clin Nurs 19(23-24): 3443-3452. DOI: 10.1111/j.13652702.2010.03318.x.

48. Veeramah V (2016). The use of evidenced-based information by nurses and midwives to inform practice. J Clin Nurs 25: 340-350. DOI: 10.1111/jocn.13054.

49. Wang LP, Jiang XL, Wang L, Wang GR, Bai YJ (2013). Barriers to and facilitators of research utilization: a survey of registered nurses in China. PLOS One 8(11): e81908. DOI: 10.1371/ journal.pone.0081908.

50. World Health Organization (2010). A Global Survey Monitoring Progress in Nursing and Midwifery. Geneva: Health Professions Networks Nursing \& Midwifery Human Resources for Health.

51. Yava A, Tosun N, Cicek H, Yavan T, Terakye G, Hatipoglu S (2009). Nurses' perceptions of the barriers to and the facilitators of research utilization in Turkey. Appl Nurs Res 22(3): 166-175. DOI: 10.1016/j.apnr.2007.11.003.

52. Zhou F, Maier M, Hao Y, Tang L, Guo H, Liu H, Liu Y (2015). Barriers to research utilization among registered nurses in traditional Chinese medicine hospitals: a cross-sectional survey in China. Evidence Based Complementary and Alternative Medicine, 2015: 1-8. DOI: 10.1155/2015/475340. 